\title{
Keragaman Permudaan Pohon di Area Sumber Air Blok Seda, Taman Nasional Gunung Ciremai
}

\section{Diversity of Tree Seedlings in Water Springs Area Seda Block, Mount Ciremai National Parks}

\author{
SLAMET ARIF SUSANTO ${ }^{{ }^{*}}$, DIANTI MAYADIKA PUTRI ${ }^{1}$, ILMA RAHMAWATI ${ }^{1}$, MADE ARI SANJAYA ${ }^{1}$, \\ SULISTIJORINI SULISTIJORINI ${ }^{2}$
}

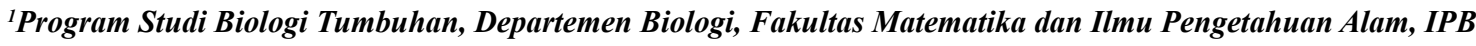

University, Bogor 16680

${ }^{2}$ Departement of Biology, Faculty of Mathematics and Natural Sciences IPB University, Jl. Agatis Kampus IPB, Bogor 16680

Diterima 24 September 2021/Disetujui 27 Desember 2021

\begin{abstract}
Water availability in Mount Ciremai National Parks (MCNP) is influenced by sustainability of the vegetation. Therefore, tree regeneration around the water springs area needs to be investigated to maintain the sustainability of water springs ecosystem in the future. The purpose of this study was to analyzed and identify natural seedlings of tree regeneration around the water springs area Seda Block MCNP. The collections of vegetation and abiotic data was carried out on 9 sample plots measuring $3 \times 3 \mathrm{~m}$ which is purposively placed around water springs. Result show that vegetation in water springs dominate by seedlings Ficus sp., Ficus hemsleyana, and Trevesia sundaica. ShannonWeiner diversity index in this location was moderate, but evenness and dominance index classified as high and low, respectively. Overall, seedling of trees dominated by orthodox seed-type and shade tolerant plant. The vegetation in this study dominated by plants categorized least concern (LC) based on IUCN red list. Microclimatic of study site affects 58.89\% on abundance and distribution of tree seedlings. Therefore, the springs are in the Seda Block MCNP needs to be conserved and maintain its natural vegetation.
\end{abstract}

Key words: Mount Ciremai National Park, eco-hydrology, canonical correspondent analysis, conservation

\section{PENDAHULUAN}

Salah satu fungsi vital Taman Nasional Gunung Ciremai (TNGC) adalah sebagai penyedia sumber air bagi masyarakat di Kabupaten Kuningan dan sekitarnya. Letak TNGC yang berada di tengahtengah 4 Kabupetan yakni Kuningan, Majalengka, Cirebon, dan Ciamis memiliki fungsi ekohidrologi yang amat penting. Analisis peta kawasan oleh Noerdjito dan Mawardi (2008) menunjukkan bahwa mata air dari lereng-lereng Gunung Ciremai muncul pada ketinggian 400-800 mdpl. Pada ketinggian tersebut didominasi bukit yang terjal dan sungai-sungai kecil yang menyebabkan wilayah lereng tersebut selalu lembap. Tingginya potensi sumber air yang dimiliki kawasan konservasi TNGC menyebabkan prioritas konservasi pada restorasi fungsi hidrologi hutan mencapai 58.25\% (Gunawan dan Subiandono 2014).

*Penulis korespondensi:

E-mail: susanto.slametarif96@gmail.com
Dalam lingkup ekosistem tropis ketersediaan air di area hutan tidak dapat dipisahkan dengan aspek vegetasi. Vegetasi memiliki peran yang penting untuk proses konservasi tanah dan air (Chappell et al. 2001; Beck et al. 2013; Filoso et al. 2017), khususnya pada area taman nasional (van Baukering et al. 2003; Kleinhans dan Gerold 2004; Yuniarsih et al. 2014). Daya dukung ekosistem hutan terhadap ketersediaan air dapat diteruskan secara kontinu melalui regenerasi vegetasi. Regenerasi vegetasi memiliki peran penting untuk memprediksi kelimpahan vegetasi di masa mendatang. Penelitian Freitas et al. (2019) mengungkapkan bahwa kehadiran fase pertumbuhan anakan pohon (semai dan pancang) memiliki kontribusi maksimal untuk mendukung keberlanjutan ekosistem hutan. Regenerasi vegetasi di hutan juga berpengaruh pada pada kualitas dan kuantitas sumber air suatu ekosistem. Penelitian García-Leoz et al. (2018) menunjukkan bahwa semakin meningkat umur regenerasi hutan pasca suksesi diikuti oleh peningkatan komposisi 
vegetasi, sehingga kadar air tanah cenderung meningkat dan kekeruhan air menurun.

Desa Seda merupakan salah satu desa di TNGC yang memiliki potensi sumber air sangat melimpah. Desa ini berbatasan langsung dengan kawasan inti dari TNGC dan memiliki tipe ekosistem yang tergolong masih alami (Gunawan dan Subiandono 2014). Penelitian secara komprehensif tentang vegetasi pada kawasan hutan Blok Seda TNGC telah dilakukan oleh Gunawan dan Subiandono (2014), Gunawan (2015), dan Hayati et al. (2021). Secara umum hasil penelitian tersebut mendeskripsikan secara kuantitatif struktur dan keragaman hutan, proses suksesi sekunder, beserta beberapa jenis tumbuhan indikator untuk rehabilitasi umur lahan suksesi di TNGC. Meskipun demikian, belum tersedia informasi spesifik yang membahas potensi regenerasi permudaan pohon yang tumbuh secara alami di area sumber air TNGC.

Beberapa area bukit yang terjal di hutan Blok Seda TNGC memiliki sumber air yang cukup melimpah. Hal ini turut didukung oleh aspek vegetasi yang cenderung menutupi bagian bukit yang terjal. Aspek regenerasi alami pada area sumber air di hutan Blok Seda TNGC perlu diinvestigasi, karena terkait dengan proses konservasi dan sebagai bagian untuk menjaga eksistensi sumber air TNGC pada masa mendatang. Penelitian ini dilakukan sebagai langkah awal untuk mendukung upaya rehabilitasi hutan Blok Seda TNGC berdasarkan karakteristik potensi permudaan pohon di area sumber air. Oleh sebab itu, tujuan penelitian ini adalah menganalisis dan mengidentifikasi permudaan pohon alami yang berada di area sumber air hutan Blok Seda TNGC.

\section{BAHAN DAN METODE}

Lokasi Penelitian. Penelitian ini dilaksanakan pada hutan Blok Seda, Seksi Pengelolaan Wilayah I Kuningan, Taman Nasional Gunung Ciremai, Kabupaten Kuningan, Provinsi Jawa Barat. Berdasarkan klasifikasi iklim Schmidt dan Fergusson, lokasi penelitian termasuk ke dalam tipe $\mathrm{B}$ dan $\mathrm{C}$ dengan rerata curah hujan sebanyak 2,000-4,000 $\mathrm{mm} /$ tahun dan temperatur udara berkisar $18-27^{\circ} \mathrm{C}$. Apabila didasarkan pada klasifikasi iklim Köppen-Geiger area penelitian termasuk dalam tipe Af yang memiliki curah hujan $>2,000 \mathrm{~mm} /$ tahun (Peel et al. 2007).

Hutan Blok Seda TNGC sejatinya termasuk dalam zona inti kawasan taman nasional karena berfungsi sebagai kawasan penyangga kehidupan dan memiliki fungsi hidrologis yang penting sebagai daerah resapan dan sumber air (BBTNGC 2017). Namun, akibat banyaknya perambahan hutan selama beberapa dekade terakhir, saat ini area tersebut dimasukkan ke dalam area rehabilitasi. Meskipun begitu, kondisi lereng yang cukup terjal serta sulitnya akses ke arah sumber air, menyebabkan area lokasi penelitian masih tergolong hutan primer yang alami. Petak pengamatan secara geografis terletak pada $6^{\circ} 49^{\prime} 56^{\prime \prime} \mathrm{LS}$ dan $108^{\circ} 27^{\prime}$ 29" BT (Gambar 1) dan memiliki ketinggian 517531 meter di atas permukaan laut.

Prosedur Penelitian. Penelitian ini merupakan studi eksploratif yang dilakukan selama 3 hari pada bulan Maret 2020. Pengambilan data permudaan pohon di area sumber air hutan Blok Seda TNGC dilakukan secara purposif sampling, karena lokasi penelitian memiliki topografi yang terjal (lihat peta kontur pada Gambar 1) dan vegetasi yang cenderung rapat. Sebelum mencapai lokasi penelitian, kami harus melalui hutan bambu dan semak yang cukup rapat di lereng-lereng bukit yang terjal. Pendataan permudaan pohon jenis-jenis tumbuhan di hutan Blok Seda TNGC dilakukan pada sembilan petak contoh berukuran 3 $\times 3 \mathrm{~m}$. Seluruh petak contoh tersebut berada di area sumber air (Gambar 1). Lokasi penelitian berada di bawah salah satu sumber mata air yang kurang lebih berjarak $500 \mathrm{~m}$. Permudaan pohon didata pada fase semai yang memiliki tinggi kurang dari $150 \mathrm{~cm}$.

Data permudaan pohon dikumpulkan dengan cara mencatat nama jenis tumbuhan, jumlah individu, dan tutupan jenis. Faktor lingkungan lokal yang meliputi temperatur udara, temperatur tanah, kelembapan udara, kelembapan tanah, $\mathrm{pH}$ tanah, intensitas cahaya, dan kecepatan angin diukur secara langsung pada masingmasing petak berukuran $3 \times 3 \mathrm{~m}$. Pengukuran faktor lingkungan lokal diulang sebanyak sembilan kali untuk tiap-tiap petak.

Analisis Data. Data vegetasi dianalisis dengan metode deskriptif kuantitatif dengan menentukan indeks nilai penting (INP) masing-masing jenis. Penentuan INP didasarkan nilai kumulatif dari kerapatan relatif (KR), frekuensi relatif (FR), dan dominansi relatif (DR). Penentuan dominansi berdasarkan pengamatan tutupan jenis secara visual di lapangan. Beberapa indeks lain yang digunakan untuk menilai permudaan pohon di TNGC antara lain indeks keanekaragaman Shannon-Weiner $\left(\mathrm{H}^{\prime}\right)$ berbasis bilangan Euler, indeks kemerataan (E), dan indeks dominansi (C). Acuan untuk penentuan nilai dari indeks-indeks tersebut mengacu pada Magurran (2004).

Sebagai upaya konservasi, seluruh jenis permudaan pohon yang berhasil diinventarisasi dan dikenali akan dilacak status konservasinya berdasarkan International Union for Conservation of Nature (IUCN) melalui website www.iucnredlist.org. Aspek status konservasi menjadi dasar untuk ekspansi suatu taman nasional 

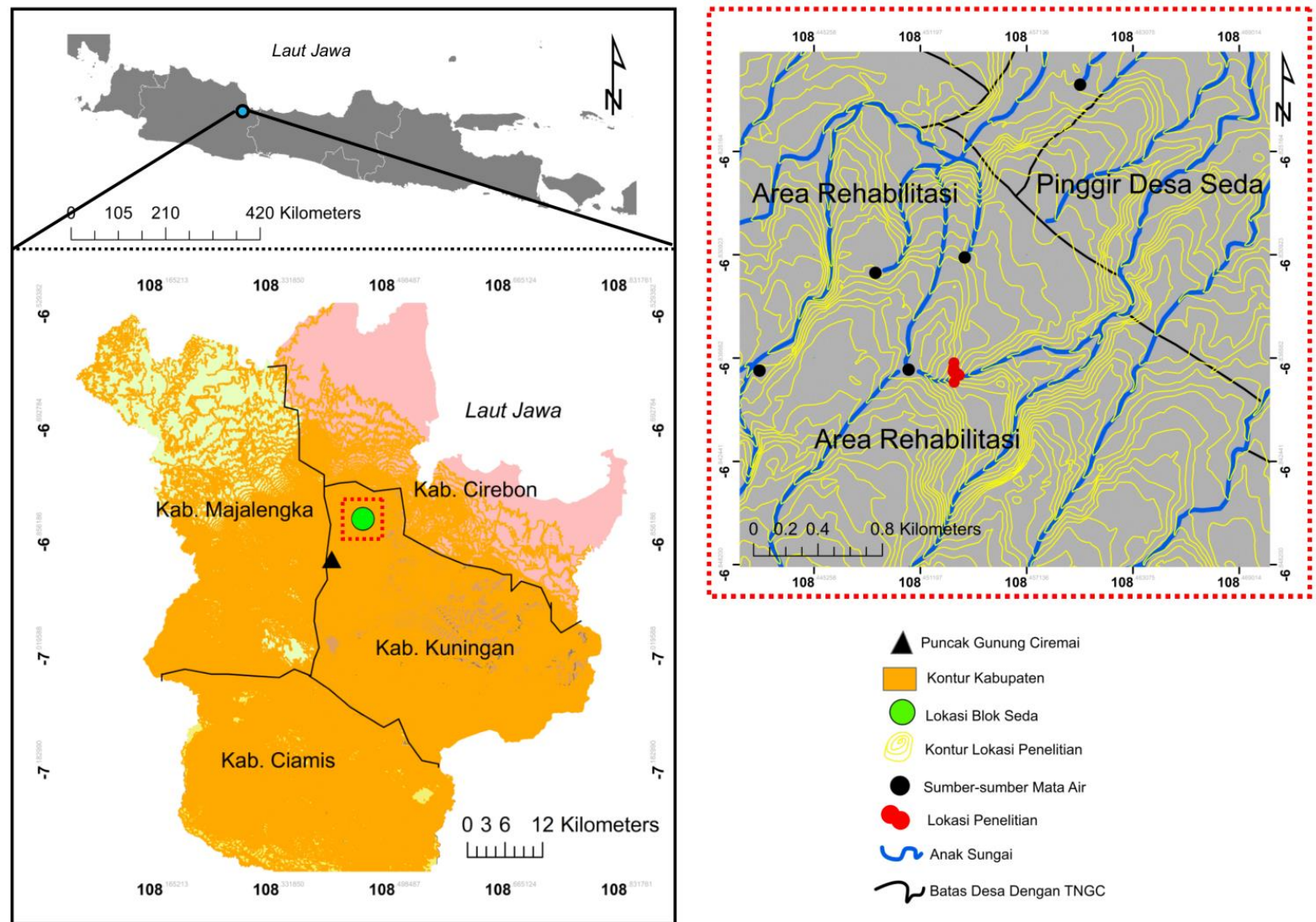

Gambar 1. Peta lokasi penelitian di area sumber air hutan Blok Seda TNGC. Lokasi penelitian berjarak \pm 8 km dari puncak Gunung Ciremai

dan manajemen kawasan berkelanjutan. Adapun, informasi mengenai potensi permudaan pohon di TNGC juga ditelusuri berdasarkan status sifat biji yaitu ortodoks, rekalsitran, atau intermediet menurut beberapa literatur.

Keterkaitan antara faktor lingkungan lokal yang telah diukur terhadap kelimpahan maupun distribusi permudaan pohon dianalisis berdasarkan canonical correspondent analysis (CCA) menggunakan peranti Past v. 4.03 untuk Windows (Past Inc. Ltd). Analisis ini mengelompokkan jenis-jenis tumbuhan berdasarkan preferensi habitat yang paling dominan serta keterkaitan antara beberapa faktor lingkungan lokal.

\section{HASIL}

Kondisi Biofisik Lokasi Penelitian. Area petak penelitian cenderung memiliki kelembapan udara yang tinggi (79.5-88.9\%), serta memiliki kisaran intensitas cahaya matahari yang bervariasi mulai 252 hingga 2,080 lux. Adapun, temperatur udara rata-rata pada lokasi pengamatan yaitu $26.3^{\circ} \mathrm{C}$. Kelembapan tanah berkisar 83-90\%, sedangkan rata-rata $\mathrm{pH}$ tanah bernilai 6.7. Kondisi lingkungan lokasi penelitian ada yang cenderung sejuk karena tertutupi oleh kanopi pohon, di sisi lain ada juga yang relatif terbuka tanpa tutupan kanopi (Gambar 2).
Komposisi Vegetasi Permudaan Pohon. Vegetasi permudaan pohon di area sumber air hutan Blok Seda TNGC didominasi oleh Ficus sp., Ficus hemsleyana, dan Trevesia sundaica (Tabel 1). Ficus sp. memiliki kerapatan relatif dan dominansi relatif tertinggi dibanding seluruh jenis lainnya $(>20 \%)$. Meskipun begitu, frekuensi relatif jenis tersebut lebih rendah (hanya $7.80 \%$ ) dibandingkan $F$. hemsleyana dan T. sundaica. Di sisi lain, T. sundaica memiliki frekuensi relatif tertinggi dibanding seluruh jenis lainnya, mengindikasikan bahwa jenis tersebut terdistribusi lebih merata. Adapun, jenis Aglaia sp. dan Melicope latifolia termasuk ke dalam jenis dominan akibat memiliki kerapatan relatif yang cenderung lebih tinggi. Suku tumbuhan dominan pada lokasi penelitian meliputi Moraceae, Euphorbiaceae, Meliaceae, dan Rutaceae. Secara spesifik suku Moraceae dan Rutaceae mendominasi 10 tumbuhan dominan berdasarkan INP (Tabel 1).

Sifat Benih, Karakter Tumbuh, dan Status Konservasi Permudaan Pohon. Hasil penelitian mencatat sebanyak 28 jenis tumbuhan yang terdiri atas 14 suku memiliki potensi sebagai sumber benih dari di hutan Blok Seda TNGC (Tabel 2). Permudaan pohon yang dijumpai di area sumber air hutan Blok Seda TNGC 75\% didominasi oleh jenis yang memiliki karakter benih ortodoks. Hampir $60 \%$ dari seluruh jenis permudaan pohon termasuk toleran terhadap 


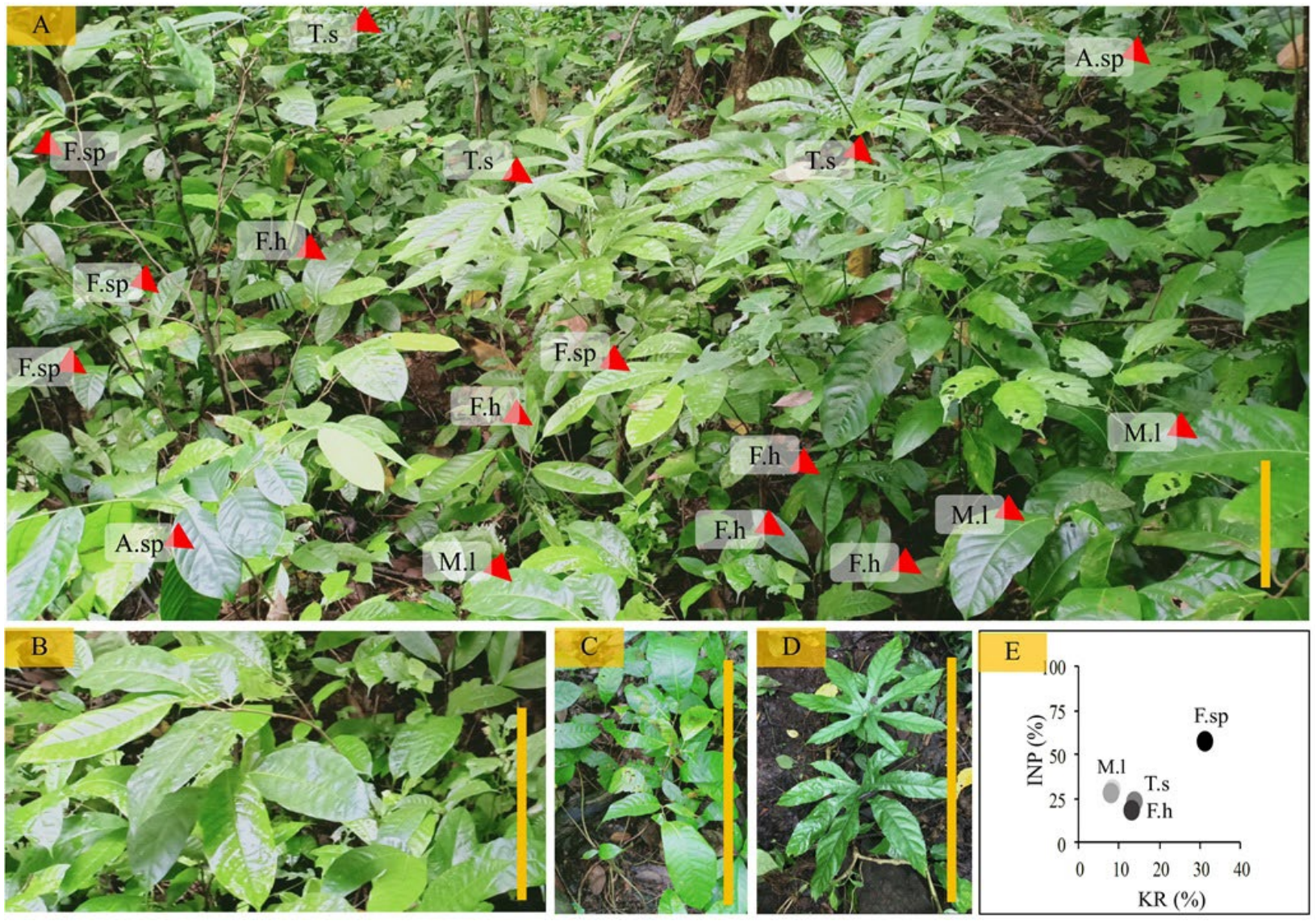

Gambar 2. Keadaan lokasi penelitian beserta gambaran tutupan vegetasi permudaan pohon (A). Gambar B, C, dan D masingmasing merupakan jenis Ficus sp., Ficus hemsleyana, dan Trevesia sundaica. Gambar E menunjukkan hubungan kerapatan relatif (KR) permudaan pohon terhadap indeks nilai penting (INP). Keterangan singkatan: F.sp = Ficus sp., F.h $=$ Ficus hemsleyana, T.s $=$ Trevesia sundaica, A.sp = Aglaia sp., M.1 = Melicope latifolia. Skala foto $\pm 60 \mathrm{~cm}$.

Tabel 1. Komposisi vegetasi permudaan pohon dominan di area sumber air hutan Blok Seda TNGC

\begin{tabular}{llrrrr}
\hline Nama jenis & Suku & KR & FR & DR & INP \\
\hline Ficus sp. & Moraceae & 31.30 & 5.80 & 20.30 & 57.68 \\
Ficus hemsleyana & Moraceae & 8.40 & 7.80 & 13.20 & 29.68 \\
Trevesia sundaica & Araliaceae & 8.24 & 11.70 & 7.10 & 27.35 \\
Aglaia sp. & Meliaceae & 13.89 & 3.90 & 4.60 & 22.55 \\
Melicope latifolia & Rutaceae & 13.13 & 1.90 & 2.90 & 18.04 \\
Gomphandra javanica & Stemonuraceae & 5.95 & 1.90 & 8.70 & 16.69 \\
Melicope sp. & Rutaceae & 1.83 & 7.80 & 5.70 & 15.54 \\
Platea excelsa & Icacinaceae & 4.27 & 3.90 & 4.30 & 12.64 \\
Oreocnide rubescens & Urticaceae & 3.05 & 3.90 & 3.40 & 10.55 \\
Helicia serrate & Proteaceae & 1.83 & 5.80 & 1.10 & 9.00 \\
\hline
\end{tabular}

Tabel 2. Karakteristik sifat benih dan sifat tumbuh permudaan pohon di area sumber air hutan Blok Seda TNGC

\begin{tabular}{|c|c|c|c|c|}
\hline Suku & Nama jenis & Sifat benih & Karakter tumbuh & Status konservasi \\
\hline Apocynaceae & Tabernaemontana $\mathrm{sp}$. & Ortodoks & Toleran naungan & - \\
\hline Araliaceae & Trevesia sundaica & Ortodoks & Toleran naungan & - \\
\hline \multirow[t]{3}{*}{ Euphorbiaceae } & Homalanthus pupolneus & Ortodoks & Butuh cahaya & $\mathrm{LC}$ \\
\hline & Mallotus paniculatus & Ortodoks & Butuh cahaya & $\mathrm{LC}$ \\
\hline & Ostodes paniculata & Ortodoks & Butuh cahaya & $\mathrm{LC}$ \\
\hline Icacinaceae & Platea excelsa & - & - & $\mathrm{LC}$ \\
\hline \multirow[t]{3}{*}{ Lauraceae } & Actinodaphne glomerata & Ortodoks & Butuh cahaya & $\mathrm{LC}$ \\
\hline & Cinnamomum sintoc & Ortodoks & Toleran naungan & $\mathrm{LC}$ \\
\hline & Litsea noronhae & Ortodoks & Toleran naungan & $\mathrm{LC}$ \\
\hline \multirow[t]{4}{*}{ Meliaceae } & Aglaia sp. & Ortodoks & Toleran naungan & - \\
\hline & Aglaia argentea & Ortodoks & Toleran naungan & $\mathrm{LC}$ \\
\hline & Dysoxylum gaudichaudianum & Rekalsitran & Butuh cahaya & $\mathrm{LC}$ \\
\hline & Dysoxylum sp. & Rekalsitran & Toleran naungan & - \\
\hline Monimiaceae & Kibara coriacea & Rekalsitran & Butuh cahaya & $\mathrm{LC}$ \\
\hline Moraceae & Ficus callosa & Ortodoks & Butuh cahaya & - \\
\hline
\end{tabular}


Tabel 2. Lanjutan

\begin{tabular}{llllc}
\hline Suku & Nama jenis & Sifat benih & Karakter tumbuh & Status konservasi \\
\hline & Ficus hemsleyana & Ortodoks & Butuh cahaya & LC \\
Phyllanthaceae & Ficus sp. & Ortodoks & Butuh cahaya & - \\
Proteaceae & Antidesma montanum & Ortodoks & Butuh cahaya & LC \\
Rubiaceae & Helicia serrata & Ortodoks & Toleran naungan & - \\
& Coffea cenephora & Ortodoks & Toleran naungan & LC \\
Rutaceae & Psychotria montana & Ortodoks & Toleran naungan & - \\
& Melicope latifolia & Ortodoks & Butuh cahaya & - \\
& Melicope sp. & Ortodoks & Butuh cahaya & - \\
Sapindaceae & Belum teridentifikasi & Ortodoks & Butuh cahaya & - \\
Stemonuraceae & Arytera littoralis & Ortodoks & Butuh cahaya & LC \\
Urticaceae & Gomphandra javanica & Rekalsitran & Toleran naungan & - \\
& Boehmeria sp. & Rekalsitran & Toleran naungan & - \\
\hline
\end{tabular}

$\mathrm{LC}=$ least concern/status kurang diperhatikan berdasarkan IUCN red list

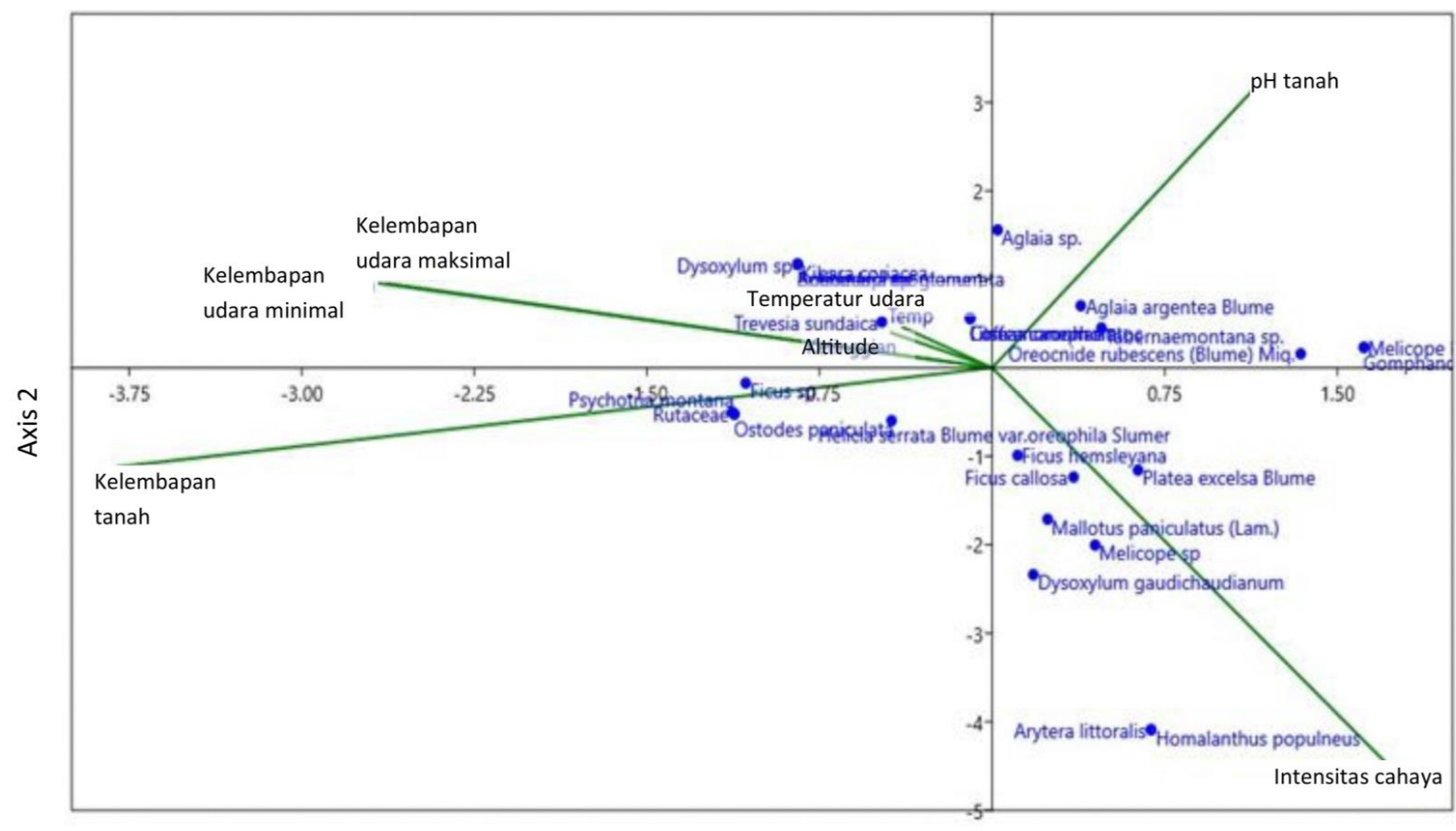

Axis 1
Gambar 4. Keterkaitan antara beberapa faktor lingkungan lokal terhadap kelimpahan dan distribusi permudaan pohon di area sumber air hutan Blok Seda TNGC

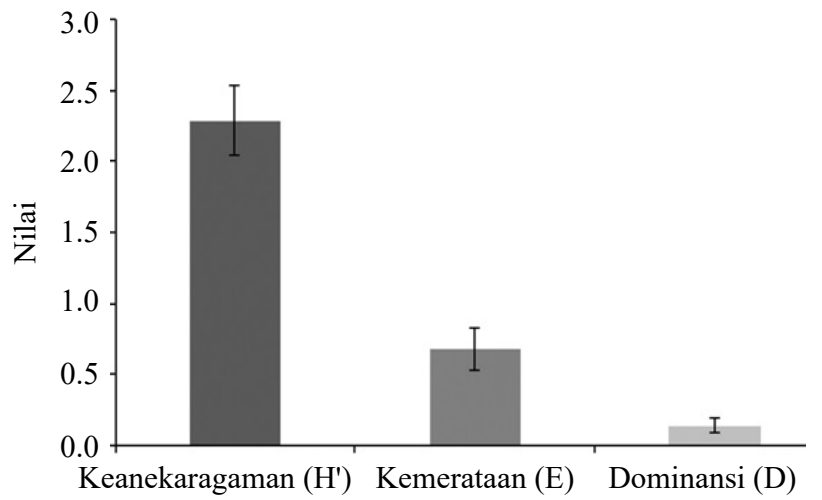

Gambar 3. Rerata indeks keanekaragaman, kemerataan, dan dominansi permudaan pohon $( \pm \mathrm{SE}$ untuk $\mathrm{n}=9)$ di area sumber air hutan Blok Seda TNGC naungan (Tabel 2). Status konservasi permudaan pohon pada penelitian ini $54 \%$ didominasi oleh least concern (LC). Sekitar $46 \%$ jenis permudaan pohon belum dapat diidentifikasi status konservasinya karena sebagian besar belum teridentifikasi hingga tingkatan jenis (Tabel 2).

Keanekaragaman, Dominasi, dan Kemerataan Permudaan Pohon. Indeks keanekaragaman dan kemerataan di antara petak penelitian cenderung bervariasi dibandingkan indeks dominansi jenis (Gambar 3). Ada variasi keanekaragaman yang lebih besar di antara petak penelitian dibandingkan variasi kemerataan maupun dominansi jenis. Secara keseluruhan indeks keanekaragaman di lokasi 
penelitian tergolong sedang (2.29), sedangkan untuk indeks kemerataan tergolong tinggi (0.68). Di sisi lain, indeks dominansi jenis tergolong rendah (0.14) dan memiliki nilai yang relatif konsisten di antara petak-petak penelitian.

Pengaruh Faktor Lingkungan Terhadap Kelimpahan Permudaan Pohon. Hasil analisis CCA menunjukkan bahwa masing-masing parameter lingkungan memengaruhi kelimpahan dan distribusi permudaan pohon (Gambar 4). Aksis 1 menjelaskan $30.89 \%$ keragaman, sedangkan aksis 2 menjelaskan $27.93 \%$ keragaman. Oleh sebab itu, biplot CCA menjelaskan 58.82\% keseluruhan keragaman faktor lingkungan. Parameter temperatur udara, ketinggian tempat (altitude), kelembapan udara minimal dan maksimal, serta kelembapan tanah memiliki korelasi positif yang erat. Parameter tersebut berkorelasi negatif terhadap intensitas cahaya matahari dan $\mathrm{pH}$ tanah.

Kelimpahan jenis Arytera littoralis dan Homalanthus pupolneus berasosiasi positif terhadap intensitas cahaya matahari. Kelimpahan dan distribusi Ficus callosa, Ficus hemsleyana, Platea excelsa, Mallotus paniculatus, Melicope sp., dan Dysoxylum gaudichaudianum membentuk kelompok tersendiri yang berasosiasi positif terhadap intensitas cahaya (Gambar 4). Kelimpahan dan distribusi Aglaia sp., Aglaia argentea, Coffea cenephora, dan Tabernaemontana sp. berasosiasi positif terhadap $\mathrm{pH}$ tanah. Kelembapan udara minimal dan maksimal, temperatur udara, dan ketinggian lokasi penelitian memengaruhi distribusi Trevesia sundaica dan Dysoxylum sp. Di sisi lain, kelimpahan dan distribusi Ostodes paniculata, Ficus sp., Psychotria montana, dan Helicia serrata dipengaruhi oleh kelembapan tanah. Seluruh permudaan pohon dominan (Ficus sp., $F$. hemsleyana, dan $T$. sundaica) dipengaruhi oleh kelembapan udara dan tanah (Gambar 4).

\section{PEMBAHASAN}

Komposisi Vegetasi Permudaan Pohon. Meskipun tidak dipelajari secara komprehensif, keterbukaan kanopi menyebabkan perbedaan intensitas cahaya matahari yang memasuki lantai hutan, sehingga berdampak pada distribusi dan kelimpahan permudaan pohon. Ficus sp. memiliki KR yang paling tinggi, namun memiliki FR yang relatif rendah mengindikasikan bahwa jenis tersebut cenderung mengelompok pada beberapa petak penelitian (Tabel 1). Di sisi lain, T. sundaica cenderung memiliki FR yang paling tinggi, namun memiliki KR dan DR yang relatif rendah. Kondisi tersebut menunjukkan bahwa $T$. sundaica lebih terdistribusi merata pada petak penelitian.

Dominasi genus Ficus spp. pada penelitian ini diduga akibat kondisi tutupan kanopi yang sedikit terbuka di area penelitian. Di samping itu, kehadiran genus Ficus spp. dan T. sundaica dapat dikaitkan dengan area lokasi penelitian yang cenderung lembap akibat banyaknya sumber air di area lokasi penelitian. Kondisi hutan yang memiliki kanopi sedikit terbuka akibat celah yang terbentuk secara alami maupun buatan menyebabkan dominasi permudaan pohon genus Ficus, Ostodes, dan Dysoxylum (Mirmanto 2014a). Apabila kanopi hutan dihilangkan, perubahan struktur vegetasi permudaan pohon menjadi lebih signifikan dan meningkatkan dominasi genus Macaranga, Piper, dan Mallotus (Slik et al. 2003; Mirmanto 2014a). Kehadiran jenis $T$. sundaica dapat menjadi indikator adanya proses pemulihan ekosistem karena jenis ini umumnya tumbuh pada area yang terganggu dan dalam tahap suksesi seperti pada kawasan hutan Resort Cidahu, Taman Nasional Gunung Halimun Salak (Mirmanto 2014a) dan area suksesi pasca letusan Gunung Merapi (Afrianto et al. 2016).

Potensi Regenerasi dan Status Konservasi Permudaan Pohon. Regenerasi secara alami di suatu ekosistem dapat dipelajari melalui karakteristik biji masing-masing tumbuhan. Permudaan pohon yang dijumpai di area sumber air hutan Blok Seda TNGC merupakan jenisjenis yang memiliki karakter benih ortodoks dan toleran terhadap naungan. Benih ortodoks adalah benih yang memiliki daya viabilitas tinggi dan dapat disimpan lebih lama dibandingkan dengan benih rekalsitran (Chin et al. 1989). Penelitian sebelumnya oleh Wanda et al. (2020) menunjukkan bahwa benih rekalsitrans lebih mendominasi potensi cadangan biji di Taman Nasional Gunung Ciremai, namun di Taman Nasional Kerinci Seblat lebih didominasi oleh benih ortodoks. Oleh sebab itu, ada variasi tipe benih antara beberapa lokasi penelitian. Meskipun begitu, pada kondisi alami benih ortodoks dapat tersimpan dalam jangka panjang di dalam tanah dan akan berkecambah ketika kondisi hutan memungkinkan, seperti adanya celah pada kanopi.

Jenis permudaan pohon dominan yang terdiri atas Ficus sp., F. hemsleyana, T. sundaica, Aglaia sp., dan Melicope spp. merupakan kelompok jenis yang memiliki benih ortodoks. Oleh sebab itu, diduga area sumber air memiliki kemampuan regenerasi vegetasi yang baik. Di sisi lain, M. latifolia yang dominan pada area penelitian disebabkan oleh kemampuan berkecambah dan tumbuh dengan baik pada tanah yang lembap. Biji dari genus Melicope akan mengalami dormansi di dalam tanah dan sulit berkecambah pada kondisi tanah yang kering (Burrows et al. 1996).

Karakter benih dan karakter tumbuh menyebabkan jenis-jenis tertentu memiliki nilai penting dalam ekosistem yang tinggi (Tabel 2). 
Hasil menunjukkan bahwa di area sumber air hutan Blok Seda TNGC didominasi oleh jenis Ficus sp. yang ditandai dengan indeks nilai penting tertinggi. Ficus sp. (57.68\%) dan F. hemsleyana (29.68\%) mendominasi area sekitar sumber air. Hal ini disebabkan pertumbuhan Ficus spp. sangat dipengaruhi oleh kelembapan udara dan kelembapan tanah. Ficus spp. dapat tumbuh di bawah kanopi, tetapi pertumbuhannya akan meningkat sejalan dengan banyaknya cahaya matahari yang diterima (Laman 1995). Lokasi penelitian yang berada di area sumber air menyebabkan Ficus spp. dapat tumbuh dengan baik karena ketersediaan air yang cukup di dalam tanah. Trevesia sundaica $(27.35 \%)$ memiliki nilai penting yang tinggi karena kemampuannya untuk tumbuh dengan baik pada kondisi hutan yang lembap dan tahan terhadap naungan. Jenis tumbuhan pionir lainnya yang dijumpai pada area ini yaitu H. populneus, Mallotus paniculatus, Ostodes paniculata menjadi indikasi proses berjalannya suksesi di area tersebut (Gunawan 2015).

Kondisi hutan sekitar sumber air tidak hanya didominasi oleh jenis pionir, tetapi juga oleh jenisjenis tumbuhan asli penanda peralihan hutan dataran rendah dengan hutan pegunungan bawah. Jenis lokal yang dijumpai di antaranya Gomphandra javanica, Dysoxylum gaudichaudianum, Actinodaphne glomerate, dan Cinnamomum sintoc merupakan jenis yang umum pada vegetasi hutan pegunungan di Jawa Barat, seperti pada hutan pegunungan bawah Taman Nasional Gunung Salak (Mirmanto 2014b; Sambas 2018). Jenis tumbuhan asli TNGC seperti C. sintoc juga telah banyak diteliti karena memiliki distribusi jenis yang luas (2-1,000 mdpl), hidup secara berkelompok, dan memiliki nilai ekonomi pada kayu yang tinggi serta potensi etnomedisin (Ismail et al. 2019).

Lebih dari $50 \%$ jenis permudaan pohon di area sumber air hutan Blok Seda TNGC memiliki status konservasi least concern (LC). Status konservasi LC menunjukkan bahwa kehadiran jenis tersebut kurang diperhatikan, meskipun terkadang sering terjadi penurunan populasinya di habitat alami (Vié et al. 2009). Oleh sebab itu, informasi tentang kelimpahan jenis yang berstatus LC pada penelitian ini dapat memberikan gambaran strategi konservasi jenis-jenis tersebut di masa mendatang.

Walaupun penelitian ini dilakukan dalam luas wilayah yang relatif sempit, tetapi memiliki jumlah jenis terkategori LC yang lebih banyak dibandingkan penelitian Susanto (2019) pada hutan sekunder berumur 15 tahun di Papua Barat dan penelitian Cahyanto et al. (2019) pada Cagar Alam Gunung Burangrang Jawa Barat. Pada beberapa penelitian, status konservasi tumbuhan LC cukup mendominasi dan umumnya memiliki indeks nilai penting yang tinggi (Susanto 2019; Fatem et al. 2020). Meskipun begitu, perbedaan spasial dan temporal penelitianpenelitian tersebut sangat berpengaruh pada banyaknya jenis yang terkategori dalam IUCN.

Keanekaragaman Permudaan Pohon di Area Sumber Air Hutan Blok Seda TNGC. Perbedaan yang signifikan pada aspek keanekaragaman tumbuhan di antara petak penelitian (Gambar 3) mengindikasikan bahwa ada perbedaan faktor iklim mikro di antara petak-petak penelitian. Area petak penelitian cenderung memiliki kanopi yang berbeda-beda bergantung pada tutupan vegetasi pohon maupun letak kelerengan. Selain itu, kisaran intensitas cahaya matahari yang amat besar pada penelitian ini (252-2,080 lux) menyebabkan variasi iklim mikro di antara petak penelitian. Intensitas cahaya matahari memiliki pengaruh yang erat $(P$ $<0.01)$ terhadap keragaman permudaan pohon maupun tumbuhan bawah (Purnomo et al. 2018). Di sisi lain, perbedaan ketinggian kanopi dapat memengaruhi intensitas cahaya matahari yang memasuki lantai hutan, sehingga berdampak pada rasio cahaya merah dan merah jauh yang memengaruhi proses perkecambahan biji maupun fotosintesis (Capers dan Chazdon 2004).

Aspek kemerataan di antara petak penelitian juga bervariasi (Gambar 3). Hal ini juga diduga akibat perbedaan kondisi petak-petak penelitian yang cenderung memiliki iklim mikro berbeda. Jenis-jenis permudaan pohon dominan seperti Ficus sp., Aglaia sp., dan M. latifolia cenderung mengelompok pada petak-petak tertentu, sehingga menyebabkan variasi nilai kemerataan di antara petak-petak penelitian. Di sisi lain, aspek dominansi permudaan pohon cenderung memiliki nilai yang lebih rendah dibandingkan keanekaragaman dan kemerataan, tetapi relatif konsisten di antara petakpetak penelitian. Hal ini mengindikasikan adanya jenis dominan lemah dan lebih sedikit persaingan dalam memperebutkan cahaya matahari.

Keterkaitan Faktor Lingkungan Terhadap Permudaan Pohon. Meskipun berada pada rentang ketinggian yang tidak berbeda jauh, penelitian ini menggambarkan bahwa ada perbedaan variasi faktor lingkungan di antara petak-petak penelitian. Variasi faktor lingkungan tersebut memengaruhi distribusi dan preferensi habitat permudaan pohon yang ditunjukkan pada Gambar 4. Kehadiran $H$. pupolneus dan A. littoralis sangat bergantung pada intensitas cahaya matahari. Homalanthus pupolneus merupakan salah satu jenis yang menjadi indikator lahan bekas kebakaran hutan di Kalimantan dan menghasilkan biomassa yang relatif lebih besar dibandingkan Piper aduncum dan Trema orientalis 
(Hiratsuka et al. 2006; Siregar 2017). Arytera littoralis merupakan jenis yang menjadi ciri khas hutan suksesi bekas pertanian di zona sub-montana Thailand (Asanok et al. 2012). Kehadiran kedua jenis tersebut mengonfirmasi bahwa area penelitian sesuai dengan peta kawasan TNGC yang berupa area rehabilitasi.

Jenis dominan dalam penelitian ini yang meliputi Ficus sp, F. hemsleyana, dan T. sundaica sangat dipengaruhi oleh kelembapan udara maupun kelembapan tanah (Gambar 4). Hal ini mengindikasikan bahwa ketiga jenis tersebut memiliki habitat yang sesuai dengan area sumber air. Kadar air yang tinggi di tanah diduga meningkatkan viabilitas perkecambahan biji jenis-jenis tersebut. Pada beberapa penelitian genus Ficus memiliki laju perkecambahan dan pertumbuhan yang dipengaruhi oleh potensial air tanah (Swagel et al. 1997; Coelho et al. 2014).

Kehadiran jenis Aglaia sp., A. argentea, dan Tabernaemontana sp. dipengaruhi oleh $\mathrm{pH}$ tanah. Meskipun begitu, $\mathrm{pH}$ tanah di lokasi penelitian cenderung netral dan memiliki kisaran yang tidak berbeda di antara petak-petak penelitian (6.6-6.8). Oleh sebab itu, ada indikasi bahwa karakteristik tanah tidak memengaruhi secara signifikan aspek pertumbuhan permudaan pohon. Secara keseluruhan, masing-masing jenis permudaan pohon memiliki ragam kemampuan bertahan hidup yang dipengaruhi oleh kondisi lingkungan lokal. Oleh sebab itu, kondisi ekosistem di area sumber air tersebut perlu dijaga untuk memastikan wilayah tersebut tetap mampu menjalankan fungsinya.

Meskipun penelitian ini dilaksanakan pada area yang terbatas, dapat disimpulkan bahwa vegetasi di area sumber air hutan Blok Seda TNGC memiliki variasi keanekaragaman, dominansi, dan kemerataan jenis di antara petak-petak penelitian. Sebagai akibatnya, ada pengaruh kuat faktor lingkungan lokal terhadap kelimpahan dan distribusi jenis permudaan pohon. Adanya dominasi biji bertipe ortodoks dan tumbuhan berstatus least concern (LC) berdasarkan IUCN di area penelitian dapat menjadi pertimbangan bahwa area sumber air tersebut memerlukan prioritas untuk dilindungi.

\section{UCAPAN TERIMA KASIH}

Ucapan terima kasih disampaikan kepada seluruh pengelola kawasan TNGC berserta masyarakat Desa Seda yang telah memberikan pendampingan dan informasi selama penelitian. Di samping itu, ucapan terima kasih disampaikan kepada Peniwidiyanti, Suci Dian Hayati, Dwika Bramasta, Nilna Kamala, dan Muhammad Basrowi atas bantuannya dalam pengambilan data di lapangan.

\section{DAFTAR PUSTAKA}

Afrianto WF, Hikmat A, Widyatmoko D. 2016. Komunitas floristik dan suksesi vegetasi setelah erupsi 2010 di Gunung Merapi Jawa Tengah. Jurnal Biologi Indonesia 12:265-276.

Asanok L, Marod D, Pattanavibool A, Nakashizuka T. 2012. Colonization of tree species along an interior-exterior gradient across the forest edge in a tropical montane forest, northwest Thailand. Tropics 21:67-80.

[BBTNGC] Balai Besar Taman Nasional Gunung Ciremai. 2017. Buku Informasi Keanekaragaman Hayati Taman Nasional Gunung Ciremai. Kuningan: Kementerian Lingkungan Hidup dan Kehutanan, Direktorat Jenderal Konservasi Sumber Daya Alam dan Ekosistem.

Beck HE, Bruijnzeel LA, van Dijk AIJM, McVicar TR, Scatena FN, Schellekens J. 2013. The impact of forest regeneration on streamflow in 12 mesoscale humid tropical catchments. Hydrology and Earth System Science 17:2613-2635.

Burrows CJ. 1996. Germination behaviour of seeds of the New Zealand woody species Melicope simplex, Myoporum laetum, Myrsine divaricata and Urtica ferox. New Zealand Journal of Botany 34:205-213.

Cahyanto T, Efendi M, Shofara RM, Dzakiyyah M, Nurlaela, Satria PG. 2019. Floristic survey of vascular plant in the submontane forest of Mt. Burangrang Nature Reserve, West Java, Indonesia. Biodiversitas 20:2197-2205.

Capers RS, Chazdon RL. 2004. Rapid assessment of understory light availability in a wet tropical forest. Agriculture and Forest Meteorology 123:177-185.

Chappell NA, Bidin K, Tych W. 2001. Modelling rainfall and canopy controls on net-precipitation beneath selectivelylogged tropical forest. Plant Ecology 153: 215-229.

Chin HF, Krishnapillay B, Stanwood PC. 1989. Seed moisture: recalcitrant vs orthodox seeds. In: Seed Moisture, Stanwood PC, McDonald MB (Eds). CSSA Spec. Pubis. No. 14. pp. 15-22.

Coelho LFM, Ribeiro MC, Pereira RAS. 2014. Water availability determines the richness and density of fig trees within Brazilian semideciduous forest landscapes. Acta Oecologica 57:109-116.

Fatem SM, Djitmau DA, Ungirwalu A, Wanma AO, Simbiak VI, Benu NMH, Tambing J, Murdjoko A. 2020. Species diversity, composition, and heterospecific associations of trees in three altitudinal gradients in Bird's Head Peninsula, Papua, Indonesia. Biodiversitas 21:3596-3605.

Filoso S, Bazerra MO, Weiss KCB, Palmer MA. 2017. Impacts of forest restoration on water yield: a systematic review. PLOS ONE 18:e0183210.

Freitas MG, Rodrigues SB, Campos-Filho EM, do Carmo GHP, da Veiga JM, Junqueira RGP, Vieira DLM. 2019. Evaluating the success of direct seedling for tropical forest restoration over ten years. Forest Ecology and Management 438:224-232.

García-Leoz V, Villegas JC, Suescún D, Flórez CP, Merino-Martín L, Betancur T, León JD. 2018. Land cover affects on water balance partitioning in the Colombian Andes: improved water availability in early steges of natural vegetation recovery. Regional Environmental Change 18:1117-1129.

Gunawan H, Subiandono E. 2014. Desain ruang restorasi ekosistem terdegradasi di Taman Nasional Gunung Ciremai, Jawa Barat. Indonesian Forest Rehabilitation Journal 2:67-78.

Gunawan H. 2015. Suksesi sekunder hutan terganggu bekas perambahan di Taman Nasional Gunung Ciremai, Jawa Barat. Prosiding Seminar Nasional Masyarakat Biodiversitas 1:1591-1599.

Hayati SD, Bramasta D, Peniwidiyanti, Kamala N, Basrowi M, Sulistijorini. 2021. Komposisi jenis dan struktur vegetasi tepi hutan, Taman Nasional Gunung Ciremai, Jawa Barat. Jurnal Sumberdaya Hayati 7:17-24.

Hiratsuka M, Toma T, Diana R, Hadriyanto D, Morikawa Y. 2006. Biomass recovery of naturally regenerated vegetation after the 1998 forest fire in East Kalimantan, Indonesia. Japan Agricultural Research Quarterly:JARQ. 40:277-282. 
Ismail AY, Kusmana C, Sudiana E, Widoso P. 2019. Population and stand structure of Cinnamomum sintoc in the low land forest of Mount Ciremai National Park, West Java, Indonesia. Biodiversitas. 20:1042-1047.

Kleinhans A, Garold G. 2004. The effects of rainforest conversion on water balance, water yield and seasonal flows in a small tropical catchment in Central Sulawesi. In: Gerold G, Fremerey M, Guhardja E (Eds). Land use, nature conservation and the stability of rainforest margins in Southeast Asia. New York (US): Springer, Berlin Heidelberg. pp 353-365.

Laman TG. 1995. Ficus stupenda germination and seedling estabilishment in a Bornean forest canopy. Ecology. 76:2617-2626.

Magurran AE. 2004. Measuring Biological Diversity. 1st ed. Oxford (UK): Blackwell Scientific.

Mirmanto E. 2014a. Permudaan alami kawasan hutan resort Cidahu, Taman Nasional Gunung Halimun-Salak, Jawa Barat. Buletin Kebun Raya 17:91-100.

Mirmanto E. 2014b. Fitososiologi hutan pegunungan di lereng tenggara Gunung Salak. Jurnal Biologi Indonesia 10:27-38.

Noerdjito M, Mawardi S. 2008. Kawasan lindung Gunung Ciremai dan kemungkinan pengelolaannya. Jurnal Biologi Indonesia 4:289-307.

Peel MC, Finlayson BL, McMahon TA. 2007. Updated world map of the Köppen-Geiger climate classification. Hydrology and Earth System Science 11:1633-1644.

Purnomo DW, Usmadi D, dan Hadiah JT. 2018. Dampak keterbukaan tajuk terhadap kelimpahan tumbuhan bawah pada tegakan Pinus oocarpa Schiede. dan Agathis alba (Lam) Foxw. Jurnal Ilmu Kehutanan. 12:61-73.

Sambas EN. 2018. Structure and composition of tree species in submontane forest of Mount Endut, Banten. AIP Conference Proceedings 2002:020018. DOI:10.1063/1.5050114
Slik JWF, Keßler PJA, van Welzen PC. 2003. Macaranga and Mallotus species (Euphorbiaceae) as indicators for disturbance in the mixed lowland dipterocarp forest of East Kalimantan (Indonesia). Ecological Indicator 2: 311-324.

Siregar M. 2017. Spatial distribution of abundant tree species at a mixed dipterocarps forest in Bukit Bangkirai, East Kalimantan three years after long drought and forest fire. Prosiding Seminar Nasional Masyarakat Biodiversitas Indonesia 3:246-251.

Susanto SA. 2019. Status konservasi vegetasi di lahan bera Womnowi Sidey Manokwari (sebuah catatan kecil inventarisasi vegetasi di hutan sekunder Papua Barat). Bioma: Jurnal Biologi Makassar 4:107-120.

Swagel NE, Bernhard AVH, Ellmore GS. 1997. Substrate water potential constraints on germination of the strangler fig Ficus aurea (Moraceae). Americal Journal of Botany. 84:716-722

van Baukering VJH, Cesar HSJ, Janssen MA. 2003. Economic valuation of the Leuser National Park on Sumatra, Indonesia. Ecological Economic 44:43-62.

Vié JC, Hilton-Taylor C, Stuart SN. 2009. Wildlife in a Changing World: An analysis of the 2008 IUCNRed List of Threatened Species. IUCN: Gland, Switzerland. pp 180.

Wanda IF, Oksari AA, Sahromi, Mimin, Latifah D. 2020. Seed exploration and conservation in Ciremai Mountai National Park and Kerinci Seblat National Park. IOP Conf. Series: Earth and Environmental Science 457:012026. DOI: 0.1088/1755- 1315/457/1/012026

Yuniarsih A, Marsono D, Pudyatmoko S, Sadono R. 2014. Zonasi taman nasional gunung ciremai berdasarkan sensitivitas kawasan dan aktivitas masyarakat. Jurnal Penelitian Hutan dan Konservasi Alam 11:239-259. 